\title{
PREDICTIVE SUCCESS FACTORS IN SCHOOL PERFORMANCE: AN ANALYSIS OF THE LARGE-SCALE ASESSMENT IN BRAZIL
}

\author{
Ivonaldo Vicente da Silva ${ }^{1}$, Márcia Terra da Silva ${ }^{2}$ and Saturnina Alves da Silva Martins ${ }^{1}$ \\ ${ }^{1} \mathrm{Me}$. \\ ${ }^{2}$ Dra. \\ Paulista University, Dr. Bacelar Street, 1212 - 4th Floor - Vila Clementino - São Paulo - SP - Brazil - Cep: 04026-002
}

\begin{abstract}
With the advent of new technologies and the strengthening of the concept of Industry 4.0, it becomes important to observe the issue of the need for more qualified and up-to-date professionals concerning the labor market. Thus, there is a need to investigate the level of school performance, especially among high school graduates, who will be the ones who will most quickly enter the labor market. In order to compose the research data, the results of the SAEB large-scale evaluation of the year 2015 in the Portuguese Language and Mathematics proficiency were used. The data were collected, standardized and the results presented in groupings by levels, obeying a scale of 0 to 10. RapidMiner software was used for data mining and decision tree construction. The central objective was to identify the best predictive factors for students' performance equal to or greater than 350 points (level 6). The results showed that there is a significant percentage of students with scores lower than 225 points in the two proficiencies analyzed, considered by the government as a concern, since these students did not learn the necessary minimum. The decision trees demonstrated that the level of schooling of the parents or guardians of students can be considered important and fundamental factors for school performance
\end{abstract}

\section{KEYWORDS}

School Performance, SAEB, Data Mining

\section{INTRODUCTION}

In Brazil, the young person who wishes to complete a higher education course must pass through all the basic education cycles, composed of Elementary and Middle School. The Elementary School consists of a cycle of nine grades and the High School for three. In some states, the fourth grade of high school is already being tested.

Based on the need for better monitoring of the quality of education, the government created an indicator called the Basic Education Performance Indicator (IDEB) and established it through the National Education Plan - PNE (MEC, 2014). One of the goals of the PNE is that the IDEB index for national education should be 6.0 by the year 2022. Each Brazilian state has its proportional target, but that converges to the national target set for 2022, however in 2015 no state has reached its goal for high school

The IDEB index is composed of data from the School Census and the performance in the large-scale evaluation of the Basic Education Evaluation System (SAEB). This system evaluates students graduating from Elementary and High School (INEP, 2018a).

Each year the labor market receives several individuals, high school graduated, looking for occupation and professional development. A large proportion of these individuals do not yet have professional qualifications, but they need to start their careers.

It is known that the Brazilian educational system suffers from several deficiencies, as its structure, teaching training, safety, access to technological means among other factors. However, several authors corroborate the fact that preparing the young, and future professionals for the job market requires a model of education based on quality and directed towards the changes of this market (Castro and Carvalho, 2013; Alves and Silva, 2013 ; Ferraz and Abreu, 2015; Hypolito and Hypolito, 2015). 
Some studies point out that family participation can be a crucial factor in students' school performance, because when there is better monitoring and interest, especially parental participation, in the school routine of children and young people, it is observed that school performance (Nogueira et al. 2015, Gomes, 2016; Zafani and Omote, 2016; Mato et al, 2017; Silveira and Brittes, 2017).

With the advent of the so-called Fourth Industrial Revolution, the labor market starts to demand more skills and abilities from the new professional. Competencies and Skills based on communication, technological knowledge and abstraction power to understand the environment based on logical and mathematic reasoning, become basic prerequisites for the individual ables to maintain and design his professional career (Sátyro et al. 2018)

The high school graduate, usually still without much qualification, needs support and guidance in order to address the labor market, since on the one hand there is a lack of experience and on the other a labor market that seeks increasingly qualified professionals (Comazzetto et al. 2016). It is important to note that the individual with the highest educational level and professional qualification is more likely to evolve professionally. (Sabóia et al. 2016; Messias and Santos, 2018)

Based on a scenario that places on the opposite sides the young person with no professional experience and the highly selective labor market, it is necessary to investigate the level of school performance of high school graduates and identify the factors that contribute or influence their performance. The population universe was composed of the results of the proficiencies in Portuguese Language and Mathematics of the students participating in the SAEB evaluation of the year 2015.

The results of this work will can to contribute with greater knowledge regarding the difficulties of learning in each proficiency analyzed and the factors that contribute to better performance in large scale evaluation, so that the government and society can adapt the public policies, in order to strengthen the work in these predictive factors and in others that are directly related to the school performance.

\section{BODY OF PAPER}

\subsection{Methodological Path}

In order for the researcher to be able to conduct his or her work in a targeted manner and to mitigate possible failures, both in data collection and in interpretations of results, it is necessary to define the entire methodological course, including method, techniques and, in particular, researcher creativity, always observing the objectives one wishes to attain.

Firstly, for the development of this study, bibliographic research was carried out in databases such as Scielo, Google Scholar and Web of Science in order to identify the predictive factors of school performance.

Next, SAEB2015 data were collected on the website of the National Institute of Anísio Teixeira - INEP, including complementary documents such as data dictionaries, proficiency scales, among others (INEP, 2018b). The results range from 0 to 500 and are organized in a range of 25 points, with the lowest, from 0 to 225 , being considered as level zero. 70698 students participated in this edition, 39326 girls and 31373 boys.

Table 1 presents the results for the proficiencies in Portuguese Language and Mathematics organized by level and gender of the students. The groupings were performed according to the performance of each proficiency, that is, in each level was described the total number of students who had a final grade within the analyzed range. Ex: Level 1> = 225 and $<250$ points.

After this phase, in order to try to identify important factors in the prediction of good results in the SAEB evaluation, some attributes were separated, according to Tanle 2, for the construction of Decision Trees with support of the data mining technique. The software used for data mining was RapidMiner. The results will be analyzed in the topic Analysis of Results. 
Table 1. Number of students in each SAEB 2015 Proficiency

\begin{tabular}{|c|c|c|c|c|c|c|c|c|}
\hline \multirow{2}{*}{ Scale } & \multicolumn{4}{|c|}{ Girls } & \multicolumn{4}{|c|}{ Boys } \\
\hline & PORT & $\%$ PORT & MAT & \% MAT & PORT & $\%$ PORT & MAT & \% MAT \\
\hline Level $0<225$ & 6555 & 16,669 & 6863 & 17,452 & 7476 & 23,829 & 4829 & 15,392 \\
\hline Level $1 \quad 225<250$ & 5394 & 13,716 & 8987 & 22,853 & 4470 & 14,248 & 5679 & 18,102 \\
\hline Level $2250<275$ & 6122 & 15,568 & 8155 & 20,737 & 4736 & 15,096 & 5627 & 17,936 \\
\hline Level $3 \quad 275<300$ & 6376 & 16,214 & 5437 & 13,826 & 4419 & 14,085 & 4128 & 13,158 \\
\hline Level $4300<325$ & 5778 & 14,693 & 3444 & 8,758 & 3902 & 12,437 & 3184 & 10,149 \\
\hline Level $5325<350$ & 4747 & 12,071 & 2499 & 6,355 & 3278 & 10,448 & 2594 & 8,268 \\
\hline Level $6350<375$ & 2937 & 7,469 & 1907 & 4,849 & 2078 & 6,624 & 2139 & 6,818 \\
\hline Level $7 \quad 375<400$ & 1208 & 3,072 & 1159 & 2,947 & 846 & 2,697 & 1577 & 5,027 \\
\hline Level $8 \quad 400<425$ & 208 & 0,529 & 631 & 1,605 & 168 & 0,535 & 999 & 3,184 \\
\hline Level $9 \quad 425<450$ & & & 213 & 0,542 & & & 505 & 1,610 \\
\hline Level $10>=450$ & & & 30 & 0,076 & & & 112 & 0,357 \\
\hline Total...: & 39325 & $\mathbf{1 0 0 , 0 0}$ & 39325 & $\mathbf{1 0 0 , 0 0}$ & 31373 & $\mathbf{1 0 0 , 0 0}$ & 31373 & $\mathbf{1 0 0 , 0 0}$ \\
\hline \multicolumn{9}{|c|}{ Note: In Portuguese Language (PORT) Level 8 includes all students with a mark above 400} \\
\hline
\end{tabular}

Source: Developed by the Author (2018)

\subsection{Analysis of Results}

It is observed a high percentage of students in level 0 , (see Table 1), considered by the government as a worrying factor because at this level, the student did not learn the minimum necessary for the proficiency. In Portuguese Language, the total number of girls at level zero was $16.67 \%$ and boys $23.83 \%$, whereas, in math, $17.45 \%$ of the girls and $15.39 \%$ of the boys have this low evaluation.

If the scale used for analysis is Level $>=6$ of the scale for proficiency, in Portuguese language the total number of girls was $11.07 \%$ and boys $9.86 \%$. In Mathematics, the total number of girls was $10.02 \%$ and boys $17.0 \%$. Both the large number of students at level zero and the low number of students at the level $>=6$ are worrisome. The differences in performance in Mathematics and Portuguese Language, among boys and girls, have already been observed in the studies of (Laros and Marciano, 2008; Laros et al. 2010), in studies involving high school students in the SAEB 2001 edition.

Then the predominant factor was verified so that the students obtained better performances in this evaluation. In this way it was necessary to use the data mining technique.

Data mining can be used to discover patterns in databases, and from these standards generate sufficient and necessary knowledge in support of decision-making (Silva et al. 2016; Provost and Fawcett, 2016).

The variables/attributes were chosen and prepared based on the forms applied to the students and the data/responses for each variable/attribute were collected from the results available by INEP (INEP, 2018b). The variables/attributes used for this study are described in Table 2.

Table 2. Variables/Attributes used for the Decision Tree

\begin{tabular}{|l|l|}
\hline \multicolumn{1}{|c|}{ Description } & \multicolumn{1}{|c|}{ ShortName } \\
\hline What is your gender? & SEX \\
\hline $\begin{array}{l}\text { Have your mother, or the woman responsible for you, } \\
\text { studied untill what grade? }\end{array}$ & MOTHER_STUDY \\
\hline $\begin{array}{l}\text { Have your father, or the man responsible for you, studied } \\
\text { untill what grade? }\end{array}$ & FATHER_STUDY \\
\hline Do your parents or guardians encourage you to study? & PARENTS_ENCOURAGE_STUDY \\
\hline $\begin{array}{l}\text { Do your parents or guardians encourage you to do } \\
\text { homework or school tasks? }\end{array}$ & PARENTS_ENCOURAGE_HOMEWORK \\
\hline
\end{tabular}




\begin{tabular}{|l|l|}
\hline Do your parents or guardians encourage you to read? & PARENTS_ENCOURAGE_READ \\
\hline $\begin{array}{l}\text { Do your parents or guardians encourage you to go to school } \\
\text { or not miss classes? }\end{array}$ & PARENTS_ENCOURAGE_GOTOSCHOOL \\
\hline $\begin{array}{l}\text { Do your parents or guardians talk to you about what } \\
\text { happens at school? }\end{array}$ & PARENTS_TALK_ABOUTSCHOOL \\
\hline Do you like to study Portuguese Language? & LIKE_PORTUGUESE \\
\hline Do you do your homework of Portuguese Language? & DO_HOMEWORK_PORTUGUESE \\
\hline $\begin{array}{l}\text { Does the teacher correct homework in Portuguese } \\
\text { Language? }\end{array}$ & TEACHER_CORRECT_PORTUGUESE \\
\hline Do you like to study Mathematics? & LIKE_MATHEMATHICS \\
\hline Do you do Mathemathics homework? & DO_HOMEWORK_MATHEMATHICS \\
\hline Does the teacher correct Mathematics homework? & TEACHER_CORRECT_MATHEMATHICS \\
\hline Do you use your school's library or reading room? & USE_LIBRARY \\
\hline Level of Proficiency (Level <6; Level> =6) & LEVEL_PROFICIENCY \\
\hline
\end{tabular}

Data normalization process was performed so that there was no inconsistency and variable/attribute with no response. In this way, all the data that were duly completed were used.

RapidMiner software was used and the technique used was classification. Data were separated into two groups one for training and one for testing. From these groups the decision trees were created, one with data for proficiency in Portuguese Language and another for Mathematics. The results were grouped using level 6 of the proficiency scale as a parameter, so the label parameter of analysis was the level on the proficiency scale (Level< 6 or Level>=6), with the objective of identifying the predominant factors for students to perform better. The results are described in Tables 3 and 4. The accuracy percentage for Portuguese Language was $89.04 \%$ and for Mathematics $86.42 \%$.

Table 3. Decision Tree for Proficiency Portuguese Language

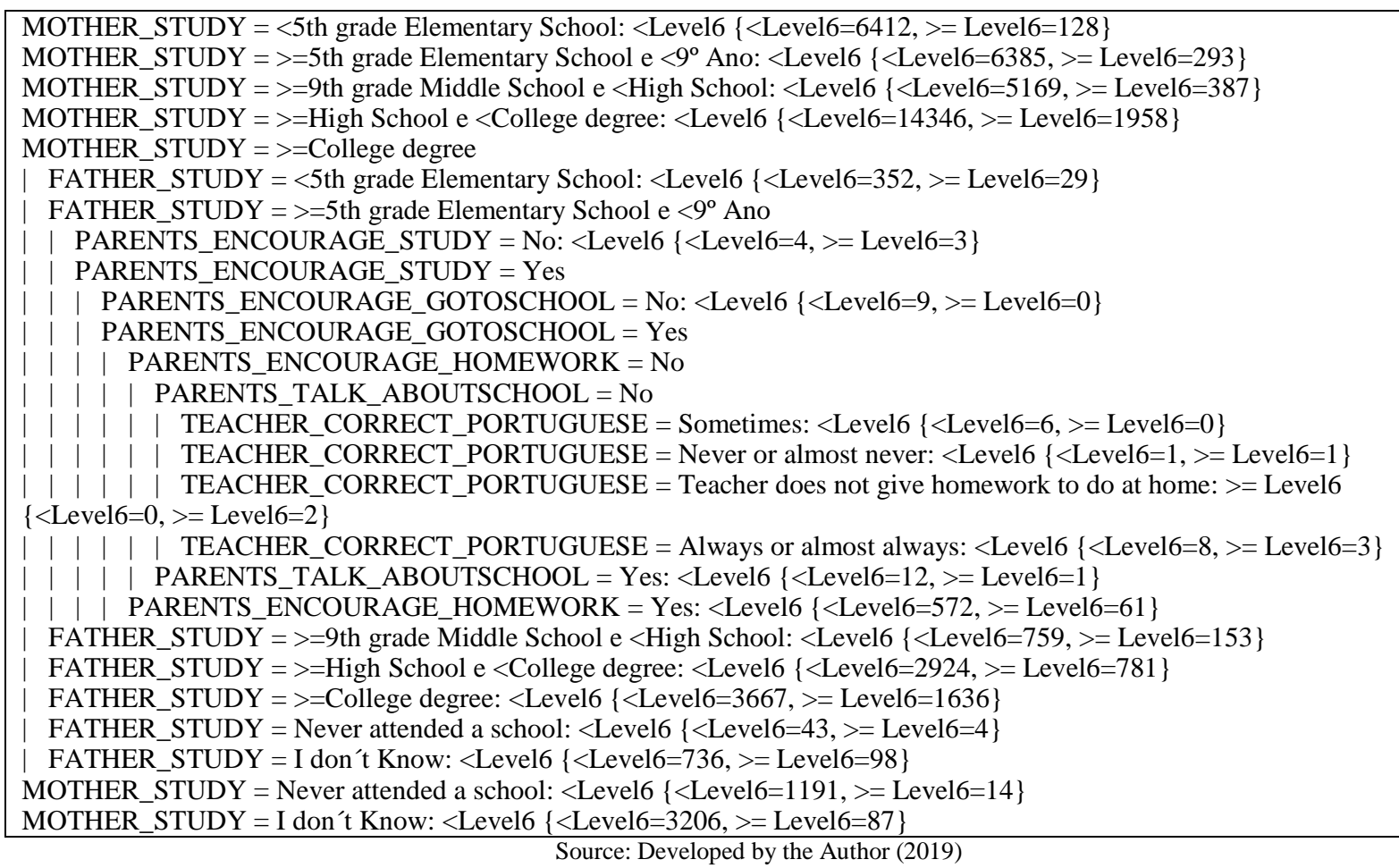


Only for didactic purposes, we will use the term SUCCESS for the level of proficiency equal to or greater than 6 (Level> =6), both for Portuguese Language and Mathematics.

It can be observed that, in the Portuguese Language case, the most critical factor presented in the decision tree is the MOTHER_STUDY. The positive variation of the mothers' schooling provides an increase of percentual of the students' success. The first four rows of the decision tree indicate that this variable alone can be used to predict the percentage of SUCCESS of the group of students.

For the condition MOTHER_STUDY="Finalized the College degree" the percentage of SUCESS reaches $30 \%$, the greater percentual among all, when the condition FATHER_STUDY="Finalized the College degree" is also true.

To complete, if the condition MOTHER_STUDY="Never Studied" the percentage of SUCCESS reaches $1.6 \%$, and if MOTHER_STUDY="Not Finalized 5th grade Elementary School" to 4.38\%, thus reinforcing the importance of the schooling level of mother or woman responsible for the student.

Some variables/attributes were not relevant to the point of appearing in the decision tree, some of which could initially have been considered as factors for school performance, such as if the student enjoys Portuguese Language (LIKE_PORTUGUESE) and uses the school library (USE_LIBRARY). From the results presented, it can be assumed that these factors are not essential for good performance in Portuguese Language proficiency.

Based on the results presented, it is clear that the schooling of the mother or woman responsible for the student is fundamental for the school performance, a fact already observed by some authors (Luiz, 2006; Gerard and Booth, 2015; Benner et al. 2016; Lobo, 2017; Fantinato and Cia, 2017)

Then the decision tree for mathematical proficiency will be analyzed.

Table 4. Decision Tree for Mathematical Proficiency

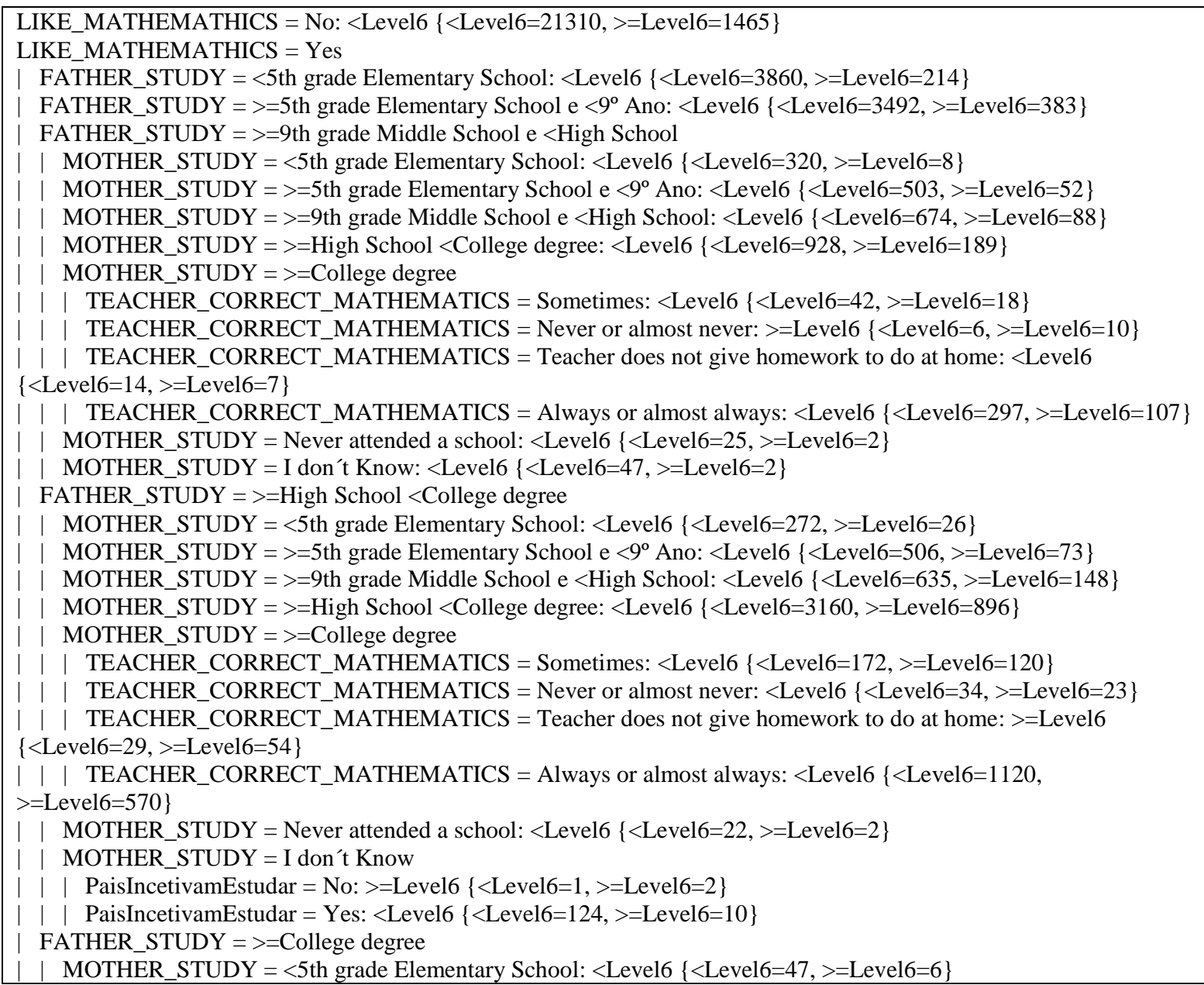




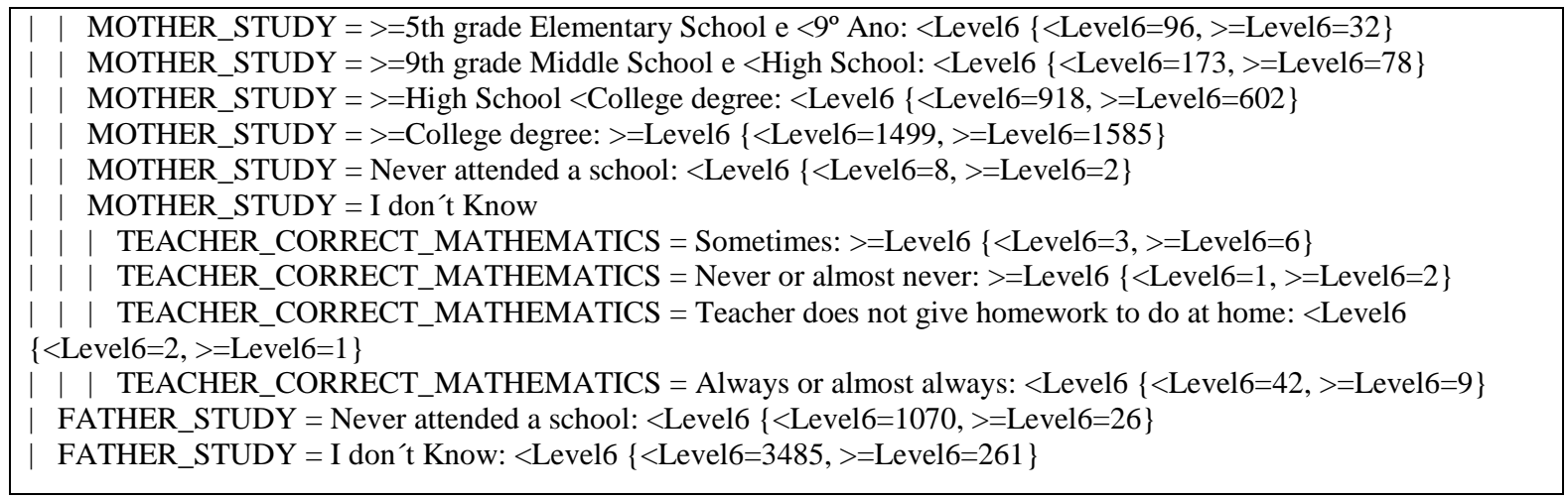

Source: Developed by the Author (2019)

The results for mathematical proficiency have shown that the main condition is whether the student likes Mathematics (LIKE_MATHEMATHICS). When the condition LIKE_MATHEMATHICS= "No" the percentage of SUCCESS reaches $6.43 \%$. Already when the condition LIKE_MATHEMATHICS="Yes" the tree shows other important conditions, one of them is the question if the father studied (FATHER_STUDY).

When the condition LIKE_MATHEMATHICS="Yes" and FATHER_STUDY="Finished College degree", the percentage of SUCCESS reaches 51.4\% when the condition MOTHER_STUDY= "Finalized the College degree" is answered and 39.6\% in the case of the condition MOTHER_STUDY="Finalized the High School, but not the College ". Both situations reinforce the assumption that parents 'or guardians' schooling significantly influences school performance.

Another important factor in the student's school routine is the teacher's participation. It is clear that the acting teacher can provide greater motivation and better student performance (Oliveira, 2016). In the conditions LIKE_MATHEMATHICS="Yes", FATHER_STUDY="Finished High School, but not College degree" and MOTHER_STUDY="Finalized the College degree" the percentage of SUCESS reaches 33,73\% when the condition TEACHER_CORRECT_MATHEMATHICS="Always or almost always "is true.

Finishing when the condition FATHER_STUDY="I do not know" the percentage of SUCCESS reaches $6.97 \%$.

The observed conditions are in line with some studies on the subject of learning in Mathematics by the students, where they also reinforce that the presence of the family becomes essential for the evolution of school performance (Laros et al. 2010; McNeal, 2015; Ross, 2016).

\section{CONCLUSIONS}

The objective of this study was to analyze the students 'performance in the SAEB 2015 large scale evaluation and to identify predictive factors of success in relation to students' performance in Portuguese Language and Mathematics proficiencies.

Initially the proficiency results showed that there is a high percentile of students, (reaching $23.8 \%$ in Portuguese Language, for boys), who presented performance compatible with level zero in both proficiencies. Likewise, the small number of students who reached a performed above level 6 is also worrisome.

In this way, it becomes necessary to have a more judicious view that can identify the deficiencies in the educational environment that may impair the performance of the students, and from that, propose changes in the educational plans and even in public policies that can offer better conditions for the learning at all levels of education (Oliveira, 2010; Oliveira and Waldhelm, 2016).

After the phases described in the methodological course, the results presented in the decision trees indicate that the level of education of parents or guardians of students is a primary factor and influences school performance. When looking at the decision trees, the results indicate that the family's role in accompanying the student's school routine may be preponderant so that the student has condition to develop and projetct his professional career. 
The labor market, more and more selective, requires skilled and updated professionals, especially in relation to new technologies and innovations, so it is necessary that the young graduates of High School have a minimum of condition, in terms of knowledge, to work in these companies. What has been observed is that the level of proficiency presented mainly in Mathematics becomes worrisome because it may be that this egress is not minimally prepared to face professional challenges that require a higher level of logical reasoning and mathematical calculations. In an environment in constant technological change, factors related to mathematical and logical reasoning may be fundamental for the maintenance of the individual in the labor market. Inclusive the level of performance presented may be an influential factor in the choice of profession (Araujo et al. 2018).

The results found may contribute to future research in the area of education, principally in the sense of improving public policies aimed at education and the participation of the family in the student's school routine. As a limitation, there is the question of the population universe of this edition of the SAEB, with the suggestion that this study can be replicated in other large-scale evaluations, including other educational levels, such as the 5th year of Elementary Education or international like PISA.

\section{ACKNOWLEDGMENT}

This work was carried out with the support of the Coordination of Improvement of Higher Level Personnel - Brazil (CAPES) - Financing Code 001.

\section{REFERENCES}

Alves, T. and Silva, R.M. da 2013. Estratificação das oportunidades educacionais no Brasil: contextos e desafios para a oferta de ensino em condições de qualidade para todos. Educação \& Sociedade 34(124), pp. 851-879.

Araújo, A.J.N. et al. 2018. Ensino profissionalizante, desempenho escolar e inserção produtiva : uma análise com dados do ENEM. http://ppe.ipea.gov.br . Available at: http://repositorio.ipea.gov.br/handle/11058/8353

Castro, J.A. de and Carvalho, C.H.A. de 2013. Necessidades e possibilidades para o financiamento da educação brasileira no plano nacional de educação. Educação \& Sociedade 34(124), pp. 829-849. doi: 10.1590/S010173302013000300010.

Comazzetto, L.R. et al. 2016. A Geração Y no Mercado de Trabalho: um Estudo Comparativo entre Gerações. Psicologia: Ciência e Profissão 36(1), pp. 145-157.

Fantinato, A.C. and Cia, F. 2017. Envolvimento parental, competência social e o desempenho acadêmico de escolares. Psicologia Argumento 29(67). Available at: https://periodicos.pucpr.br/index.php/psicologiaargumento/article/view/20401

Ferraz, R.R.N. and Abreu, J.S. 2015. Quando a Culpa do mau Desempenho Escolar não é Exclusivamente do Aluno. UNILUS Ensino e Pesquisa 12(28), pp. 96-100.

GIL, A.C. 2010. Métodos e técnicas de pesquisa social. 6th ed. São Paulo: Atlas.

Gomes, J.A.M. 2016. Os Recursos do Ambiente Familiar e a Influência no Rendimento Acadêmico. Revista Lugares de Educação 6(12), pp. 103-124.

Hypolito, Á.L.M. and Hypolito, Á.L.M. 2015. Trabalho docente e o novo Plano Nacional de Educação: valorização, formação e condições de trabalho. Cadernos CEDES 35(97), pp. 517-534. doi: 10.1590/CC0101-32622015150376.

INEP 2018a. IDEB - SAEB. Available at: http://portal.inep.gov.br/web/guest/educacao-basica/saeb

INEP 2018b. INEP - Microdados. Available at: http://portal.inep.gov.br/web/guest/microdados.

Lakatos, E.M. and Marconi, M. de A. 2017. Fundamentos de Metodologia Científica. Edição: 8 a . Atlas.

Laros, J.A. and Marciano, J.L. 2008. Índices Educacionais Associados à Proficiência em Língua Portuguesa: Um Estudo

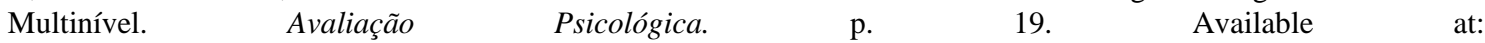
http://pepsic.bvsalud.org/scielo.php?script=sci_abstract\&pid=S167704712008000300010\&lng=en\&nrm=iso\&tlng=pt

Laros, J.A. and Marciano, J.L.P. Moura, J.A 2010. Fatores que Afetam o Desempenho na Prova De Matemática do SAEB: Um Estudo Multinível. Avaliação Psicológica, p. 14. Available at: http://www.redalyc.org/resumen.oa?id=335027283004

Lobo, G.D. 2017. Avaliação do Desempenho Escolar dos Estudantes da Região Nordeste que Realizaram o ENEM: Uma Análise com Modelos Hierárquicos. Revista Espacios 38, p. 13. 
LUZ, L.S. 2006. Os Determinantes do Desempenho Escolar: A Estratificação Educacional e o Efeito Valor Adicionado. $X V$ Encontro Nacional de Estudos Populacionais, ABEP Caxambu-MG

Matos, D.A.S. et al. 2017. Impactos das práticas familiares sobre a proficiência em Língua Portuguesa e Matemática no Ensino Fundamental. Available at: http://www.repositorio.ufop.br/handle/123456789/9797.

MEC 2014. PNE - Plano Nacional de Educação - Plano Nacional de Educação - Lei $n^{\circ}$ 13.005/2014. Available at: http://pne.mec.gov.br/18-planos-subnacionais-de-educacao/543-plano-nacional-de-educacao-lei-n-13-005-2014

Messias, J.F. and Santos, O.S. dos 2018. O Déficit Educacional e a Exclusão Tecnológica no Mercado de Trabalho Brasileiro. Brasil Para Todos - Revista Internacional 6(1). Available at: https://ojs.eniac.com.br/index.php/Anais_Sem_Int_Etn_Racial/article/view/536

MINAYO, M.C. de S. (or). 2010. Pesquisa social: teoria, método e criatividade. 29th ed. Petrópolis/RJ: Vozes.

Nogueira, R.K.S. et al. 2015. Família e Escola: Relação que Promove o Bom Rendimento Escolar dos Alunos de Duas Turmas do Ensino Fundamental em uma Escola da Região Arapiraquense. Anais do Congresso de Inovação Pedagógica em Arapiraca 1(1). Available at: http://www.seer.ufal.br/index.php/cipar/article/view/1916

Oliveira, A.C.P. de and Waldhelm, A.P.S. 2016. Liderança do diretor, clima escolar e desempenho dos alunos: qual a relação? Ensaio: Avaliação e Políticas Públicas em Educação 24(93), pp. 824-844.

Oliveira, J.A.P.F. 2016. O Que É Um Bom Professor, na Visão do Aluno: um estudo de caso em uma Instituição de Ensino Superior em Oliveira-MG. Revista Acadêmica FEOL 1(2), pp. 47-67-67.

Oliveira, L.M. de 2010. Políticas educacionais na formação da professora dos anos iniciais do ensino fundamental em cursos de licenciatura. Ensaio: Avaliação e Políticas Públicas em Educação 18(67), pp. 235-252.

Provost, F. and Fawcett, T. 2016. Data Science para Negócios. Rio de Janeiro: Alta Books.

Sabóia, A.L. et al. 2016. Adolescentes e jovens no Brasil: escolarização e inserção no mercado de trabalho. Anais, pp. $1-17$.

Sátyro, W.C. et al. eds. 2018. Indústria 4.0: Conceitos e Fundamentos. Edição: 1ª . Blucher.

Silva, L.A. da et al. 2016. Introdução à Mineração de Dados. Rio de Janeiro: Elsevier. Available at: https://www.loja.elsevier.com.br/introducao-a-mineracao-de-dados-9788535284461.html.

Silveira, R.B. and Brittes, L.R. 2017. A Participação da Família Na Escola: Desdobramentos Sobre a Evasão Escolar e a Educação Profissional E Tecnológica Na Lógica Neoliberal. Educação Básica Revista 3(1), pp. 29-46.

Sousa, M. de. 2017. Eficácia escolar e o desempenho de meninos e meninas. Aleph, p. 55 f. 